\title{
TOIMINTAMAHDOLLISUUKSIEN AVARUUS JA TOIMIJUUDEN SUUNNAT KUNTOUTTAVASSA TYÖTOIMINNASSA
}

\author{
Päivi Mäntyneva: YTM, tobtorikoulutettava, Helsingin yliopisto \\ Anna-Maria Isola: VTT, tutkimuspäällikekö, Terveyden ja byvinvoinnin laitos
}

paivi.mantyneva@helsinki.fi,anna-maria.isola@thl.fi

Janus vol. 27 (3) 2019, 246-263

\section{(J) Ja II $\mathbb{S}$}

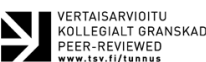

Tiivistelmä

Kuntouttavan työtoiminnan pitkäaikaistyöttömiä palveleva luonne on paikoin hämärtynyt. Osalle se on kuitenkin aito toimintamahdollisuus, joka antaa elämään merkityssisältöä. Artikkelissa syvennytään etnografisen haastattelu- ja kenttätyöaineiston avulla siihen, millaisia toimintamahdollisuuksia kuntouttava työtoiminta tarjoaa ja miten osallistujien toimijuus suuntautuu, kun kuntouttavaan työtoimintaan osallistuminen on ollut elämänkulun kannalta myönteinen käänne. Tulokset valottavat kuntouttavan työtoiminnan toimintamahdollisuuksien sisältöä ja toimijuuden suuntia ja johtavat pohtimaan, miten palvelujärjestelmää ja kuntouttavan työtoiminnan sisältöjä voitaisiin edelleen kehittää toimijuuden näkökulmasta.

\section{JOHDANTO}

Kuntouttava työtoiminta käynnistyi vuonna 2001 keinona työttömyyden seurausten lievittämiseen. Kuntouttavaan työtoimintaan osallistuminen on velvoittavaa. Siitä kieltäytyminen voi johtaa työttömyysetuuden menettämiseen. Aktivointipolitiikka on lähtökohdiltaan merkinnyt oikeuksien ja vastuiden vaa`assa sosiaalipolitiikan muutosta: aktiivisuus on muuttunut oikeudesta velvollisuudeksi. Pitkään työttömänä olleiden riippumattomuus markkinoista, dekommodifikaatio, on muuntunut aiempaa vahvemmaksi markkinariippuvuudeksi, rekommodifikaatioksi. Ilmiö on globaali, kun erilaiset vastikkeellisen sosiaaliturvan suuntaukset ovat valtavirtaistuneet ym- päri Eurooppaa ja maailmaa (Lødemed \& Trickey 2001; Walters 2000; Hiilamo ym. 2017). Hyvinvointivaltion toiminta perustuu edelleen pitkälti vanhojen sosiaalisten riskien, kuten väliaikaisen tai pysyvän ansiotulottomuuden, hallitsemiseen ja sosiaalisten ongelmien lievittämiseen (Kivipelto \& Saikkonen 2017; Hiilamo \& Saari 2010). Tämä ei kuitenkaan välttämättä toimi hyvin nyky-yhteiskunnassa ja pitkään työttömänä olleiden kohdalla.

Vaikka palkkatyö ei sinällään ole yhteiskunnasta vähentynyt, on uuden ja vanhan työn murroksessa monista heikossa työmarkkina-asemassa olevista tullut väliinputoajia (Harkko 2018). Työttömät jäävät ansiotulon lisäksi vaille useita mahdollisuuksia, työyhteisöä, ravintoe- 
tua, lomia, ansiosidonnaista eläketurvaa tai työterveyshuoltoa (Hiilamo 2014, 82). Osan kohdalla aktivoinnista on tullut pysyvää (Terävä ym. 2011; Aho ym. 2018). Tuija Oivo ja Raija Kerätär (2018) esittävät, että 81000 pitkäaikaistyöttömän joukosta jopa kolmannes on työkyvyttömiä ja väärän etuuden piirissä. Työttömien kuntoutusjärjestelmä ei ole toiminut saumattomasti ja kuntoutujan kannalta oikea-aikaisesti (Kuntoutuksen uudistamiskomitean raportti 2017). Noora Elosen, Jukka Niemelän ja Antti Salonkosken (2017) haastattelututkimuksen mukaan työttömien toimijuus ja aktiivisuus ilmenivät pyrkimyksenä takaisin töihin, työllisyyspalvelusta toiseen ja aktiiviseen elämään työelämän ulkopuolella. Aikuissosiaalityön tutkimuksessa alle 30-vuotiaiden aikuissosiaalityön miesasiakkaiden suurimpia toiveita olivat työllistyminen ja kouluttautuminen (Saikkonen ym. 2015, 37-39).

Monet tutkimukset ovat antaneet näyttöä siitä, että aktivoinnilla on myös myönteisiä hyvinvointivaikutuksia osallistujille (Karjalainen \& Karjalainen 2010; Card ym. 2010). Hyvinvointivaikutukset ovat olleet pikemminkin aktivoinnin sivuvaikutuksia kuin politiikan ensisijaisia tavoitteita (esim. Karjalainen 2013; Björklund \& Hallamaa 2013). Aktivointi voi jopa heikentää hyvän elämän edellytyksiä silloin, kun kuntouttava työtoiminta koetaan leimaavana, kun se ei vastaa tarpeisiin tai kun siihen osallistuminen on sanktioiden uhalla velvoittavaa (Halvorsen 1998; Breidahl \& Clement 2010; Bonoli 2010; Ylikännö 2017). Osallistaminen ei liioin lisää yksinhuoltajien ja lapsiperheiden virkistäytymisen mahdollisuuksia tai helpota koko perheen ruo- ka- ja matkustuskuluissa (Roivainen ym. 2011). Toistaiseksi tiedetään melko vähän siitä, miten ihmisten erilaiset taustat ja elämänkulut ovat yhteydessä siihen, mitä aktivoinnista seuraa (Leemann ym. 2016).

Pitkittyessään työttömyys on yhteydessä yhteiskunnalliseen eriarvoistumiseen sekä heikentyneeseen elämänlaatuun (Therborn 2014; Vaarama 2011). Työttömien hyvinvointikokemukset ovat systemaattisesti heikompia kuin työllisillä (Saikku 2018). Viime vuosina on ilmaantunut sosiaalipoliittisia tulkintoja siitä, että tasapaino yksilön ja kollektiivisen vastuun välillä voidaan saavuttaa siten, että pitkään työttömänä olevat saisivat tasa-arvoisia ja oikeudenmukaisia mahdollisuuksia siinä missä muutkin kansalaiset (esim. Bonvin 2008; Carpenter ym. 2007; Karjalainen 2013). Tämä on lähtökohtana Suomeen sijoittuvassa tutkimuksessamme. Käsittelemme kuntouttavaa työtoimintaa aktivointitoimenpiteissä olevien pitkäaikaistyöttömien institutionaalisena toimintatilana (Certeau 1984), jota hallinnon rationaliteetit ja työtoiminnan organisatoriset ja sosiaaliset käytännöt sekä ammatillinen toiminta määrittävät. Kaksi tutkimuskysymystämme ovat:

Millaisia toimintamahdollisuuksia kuntouttava työtoiminta tarjoaa?

Miten toimijuus suuntautuu kuntouttavassa työtoiminnassa?

Esitämme seuraavassa teoreettisia lähtökohtiamme. Tämän jälkeen kuvaamme etnografisen tutkimuksen toteutuksen eli metodin, aineiston ja kaksivaiheisen analysointitavan. Artikkelin päättää tulososio ja johtopäätökset. Lopuksi 
pohdimme, miten lakiin kirjattuja sosiaali- ja työllisyysturvan velvoittavuuteen liittyviä sisältöjä ja palvelujärjestelmää olisi kehitettävä, jotta ne vastaisivat paremmin pitkään työttömänä olevien ihmisten avun ja tuen tarpeisiin.

\section{TOIMINTAMAHDOLLISUUDET JA TOIMIJUUDEN VAHVISTAMINEN SOSIAALIPOLITIIKASSA}

Ymmärrämme toimintamahdollisuudet perusturvaksi sekä hyvinvointivaltion, järjestöjen ja yksityisten toimijoiden palveluiksi että kansalaisyhteiskunnan toiminnaksi. Toimintamahdollisuudet ylläpitävät ja edistävät ihmisten toimintakykyisyyttä ja tosiasiallista toimijuutta, mikä aikaansaa ihmisten arvostusten mukaisia myönteisï elämänmuutoksia ja siirtymiä (Hiilamo \& Saari 2010; Björklund \& Hallamaa 2013). Kiinnitymme tarkemmin Amartya Senin ja Martha Nussbaumin alkujaan kehittyvien maiden olosuhteisiin hahmottelemaan toimintamahdollisuuksien viitekehykseen (Sen \& Nussbaum 1993; Sen 1999; 2009). Lähestymistavassa yhdistyvät inhimillinen kehitys ja ihmisoikeudet.Viitekehyksen ydin on siinä, että ihmisillä pitäisi olla mahdollisuus sekä arvokkaaseen olemiseen ja tekemiseen että mahdollisuus tavoitella ja saavuttaa omia, yhteisöllisiä ja yhteiskunnan arvostamia päämääriä (Sen 1999; 2009; Robeyns 2005; Alkire \& Deneulin 2009; Cox \& Pawar 2013; den Braber 2013). Sosiaalisen oikeudenmukaisuuden näkökulmasta resurssien, hyötyjen tai hyödykkeiden tasainen jakautuminen ei yksistään riitä. Huomio olisi suunnattava siihen, mitä palvelujärjestelmän resursseilla voi tehdä, miten inhimilliset toimintamahdol- lisuudet jakautuvat ja mitä niistä seuraa. Sen $(2009,228-230)$ erottaa toimintamahdollisuuksien kaksi ulottuvuutta, jotka ovat:

Prosessinäkökulma: toimintamahdollisuudet olemisena ja tekemisenä,

Mahdollisuusnäkökulma: toimintamahdollisuudet arvostusten mukaisina ja saavutettavissa olevina tavoitteina.

Todellisten toimintamahdollisuuksien edellytyksenä on paitsi kyky ja voima toimia myös vapaus ja siihen liittyvä vastuu. Perinteinen liberalistinen tulkinta vapaudesta perustuu negatiiviselle vapaudelle, vapautena jostakin kun taas positiivinen vapaus laajentaa vapauden käsitystä vapaudeksi johonkin. Teoksessa The Idea of Justice (2009) Sen havainnollistaa vapauden käsitteitä esimerkillään Kimistä. Vapauden eri variaatiot hän nimeää skenaarioksi $\mathrm{A}, \mathrm{B}$ ja C.

Eräänä sunnuntaina Kim päättää oleilla kotona ja olla tekemättä mitään mieluummin kuin lähtee ulos (Skenaario A). Skenaariossa B Kimiä puolestaan rajoitetaan vaatimalla häntä pysyttelemään kotona, jotta hän ei saisi rangaistusta. Tässä tapauksessa Kimin vapautta rajoitetaan prosessuaalisesta näkökulmasta mutta ei mahdollisuuksien eli arvostusten mukaisten saavutusten näkökulmasta. Skenaariossa C tunkeilija sekaantuu Kimin elämään ja rajoittaa hänen vapauttaan sekä prosessin että lopputuloksen näkökulmasta. Jos todellisia toimintamahdollisuuksia tutkitaan pelkästään saavutusten näkökulmasta, ei A- ja B-skenaarioiden välillä ole eroa: Kim jää kotiin. Kun otetaan huomioon tapa, jolla Kim pää- 
tyy lopputulokseen skenaariossa A, voidaan puhua positiivisesta vapaudesta. (Sen 2009, 229-230).

David Cox ja Manohar Pawar (2013, 105-144) sekä Collin Den Braber $(2013,72)$ ovat konkretisoineet toimintamahdollisuuksien viitekehystä (capability approach, CA) Senin ajattelun pohjalta kansainvälisen sosiaalityön tavoitteiksi ja ammatillisiksi käytännöiksi. Esitämme siitä mukaelman taulukossa 1.
Alkuperäisessä Coxin ja Pawarin (2013) hahmotelmassa toimijuus on yksi toimintamahdollisuuksien ulottuvuus. Ymmärrämme toimijuuden kuitenkin erilliseksi yksilöiden, yhteisöjen ja yhteiskunnan välistä suhdetta ja dynaamista prosessia ilmentäväksi käsitteeksi, jota taulukossa 1 käsitelleet ulottuvuudet edistävät. Viime vuosikymmeninä sosiaalipoliittista keskustelua toimijuudesta on käyty useista näkökulmista. Anthony Giddensin (1984) rakenteis-

Taulukko 1. Yhteiskunnan sosiaalipoliittiset tavoitteet palvelujärjestelmän toimintamahdollisuuksien kehyksessä.

\begin{tabular}{|c|c|}
\hline $\begin{array}{l}\text { Sosiaalipoliittiset päämäärät ja } \\
\text { keskeiset käsitteet }\end{array}$ & Sosiaalialan työn tavoitteita ja sisältöjä \\
\hline $\begin{array}{l}\text { Poliittiset oikeudet ja vapaudet } \\
\text { Ihmisoikeuksien ja perustuslakien } \\
\text { mukaisuus palveluissa } \\
\text { (ammattietiikka) }\end{array}$ & $\begin{array}{l}\text { Yhteisöllinen voimauttava ja valtauttava } \\
\text { toiminta, } \\
\text { Yhteisötyö osallistavana demokratiana } \\
\text { ja kehittämäisenä, } \\
\text { Ihmiselämän arvokkuutta vaalivat palvelut }\end{array}$ \\
\hline Taloudellinen vapaus & $\begin{array}{l}\text { Lakisääteiset tuet ja harkinnanvaraisten tukien } \\
\text { käyttö, } \\
\text { Kykyisyyksien vahvistaminen (esim. } \\
\text { talousneuvonta, velkaneuvonta) }\end{array}$ \\
\hline Sosiaaliset mahdollisuudet & $\begin{array}{l}\text { Palvelut ja toiminnot toimintamahdollisuuksina, } \\
\text { Kykyisyyksien vahvistaminen (esim. } \\
\text { toimintakyky, osaaminen, taidot), } \\
\text { Voimavaralähtöisyys }\end{array}$ \\
\hline $\begin{array}{l}\text { Avoimuus } \\
\text { ja demokraattinen päätöksenteko }\end{array}$ & $\begin{array}{l}\text { Palvelut ja toiminnot sosiaalisen integraation ja } \\
\text { koheesion edistämiseksi, } \\
\text { Osallisuus- ja luottamussuhteiden } \\
\text { vahvistaminen, } \\
\text { Neuvottelu, yhteiskehittäminen }\end{array}$ \\
\hline Perusturva & $\begin{array}{l}\text { Kohtuullisen elämisen ja kulutuksen mukainen } \\
\text { perusturva ja sosiaalipalvelut }\end{array}$ \\
\hline
\end{tabular}


tumisteorian mukaan rakenteet luovat toimintamahdollisuuksia ja mahdollistavat toimijuutta mutta myös asettavat reunaehtoja toiminnalle. Kriittisen realismin hahmotelmissa rakenteet ja toimijuus määrittyvät toisistaan erillisiksi mutta vuorovaikutteisiksi elementeiksi, ja myös reflektiivisyys on olennainen osa toimijuutta (esim. Archer 1995). Interaktionistisissa suuntauksissa toimijuus ilmenee vuorovaikutteisesti puheen ja symbolien avulla. Postmoderneissa teorioissa toimijuuden käsite on liitetty identiteetteihin. (Kuusela 2011, 53-59.) Sosiaalipedagogiikassa toimijuus ymmärretään osallisuuteen liittyvänä kansalaisen kasvuprosessina, jossa yksilön autonomisuus, toiminta- ja muutosvalmiudet ja kriittinen tiedostaminen kehittyvät (Nivala 2008; Hämäläinen 2008; Nivala \& Ryynänen 2013, 27; Siisiäinen 2010, 21). Suomessa sosiaalialan empiirisissä toimijuustutkimuksissa on analysoitu esimerkiksi toimijuuden suhdetta osallisuuteen, asiakkaiden ja työntekijöitten vuorovaikutusta sekä toimijuuden kytkeytymistä valtaan ja politiikkaan ajassa (Laitinen \& Niskala 2013)

Tässä tutkimuksessa ymmärrämme toimijuuden relationaalisena käsitteenä (Lister 2004, 128; Hoggett 2000, 2001; Finch 1989; Finch \& Mason 1993; Sen 1999, 190). Ruth Listerin (2004, 126) mukaan toimijuudessa olennaista on se, missä määrin osallistujat voivat reflektoida kokemuksiaan ja käyttää valtaa elämässään riippumatta elämäntilanteesta ja olosuhteista (esim. Honneth 2012). Jyrki Jyrkämä (2008) hahmottaa toimijuuden koordinaatteja kolmiulotteisesti: toimijuus paikantuu elämänkulun, rakenteellisten tekijöiden kuten sukupolvikokemusten ja toimintaym- päristön sekä tilanteisten modaliteettien kuten kykenemisen, haluamisen ja osaamisen yhteisvaikutuksena. Toimijuuden modaliteettiavaruus on siten sekä aikaan ja paikkaan kiinnittynyttä että tilanteista liikettä, jonka avulla ihminen voi elää inhimillisten tarpeittensa ja arvostustensa mukaista elämää (emt.).

\section{TUTKIMUKSEN AINEISTOT JA MENETELMÄT}

Tutkimuksessa käytetään aineistona kuntouttavaan työtoimintaan osallistuneiden haastatteluja sekä kenttäpäiväkirja-aineistoa tutkimusta taustoittamassa (Coffey \& Atkinson 1996; Brewer 2000). Artikkelin aineistot ovat osa institutionaaliseen etnografiaa pohjautuvaa tutkimusta, jonka toteutusta vuosina 2015 ja 2016 on kuvattu aiemmissa julkaisuissa (Mäntyneva \& Hiilamo 2018; Mäntyneva 2019). Etnografinen tutkimus on aktiivista ja inhimillistä toimintaa, jossa sekä haastateltavat että tutkija tuovat oman elämänhistoriansa ja kokemusmaailmansa yhteiseen sosiaaliseen todellisuuteen (Hammersley \& Atkinson 2007). Kokemukset, kuntouttavalle työtoiminnalle annetut merkitykset ja koetut toisin toimimisen tarpeet olivat nauhoitettujen ja litteroitujen haastattelujen keskiössä. Vaikka ihminen on sidoksissa elämäntilanteeseensa, hän voi etäännyttää itsensä niistä ja tarkastella tapahtumia ja asioita suhteessa menneeseen, nykyisyyteen ja tulevaisuuteen, ajan eri ulottuvuuksissa. (Freire 1972, Hannula 2000). Kenttätyön aikana toteutuneet haastattelut painottuivat nykyhetkeen. Haastateltavat kertoivat lisäksi elämänkulustaan ennen työtoiminnan 
käynnistymistä sekä tulevaisuuskuvistaan.

Tutkimuksessa etnografian institutionaalisuus merkitsee menemistä kuntouttavan työtoiminnan arjen institutionaalisiin toimintatiloihin (Certeau 1984). Tämä tapahtui olemalla läsnä tutkijana työtoiminnassa ja syventymällä kolmen työtoiminnan tilan ja yksikön sosiaalisiin käytäntöihin. Haastattelujen ja toiminnan havainnoinnin avulla on luotu ymmärrystä siitä, miten sosiaalipolitiikka ja hallinnon rationaliteetit ja ruohonjuuritason käytännöt tarjoavat mahdollisuuksia ja suuntaavat toimijuutta (Smith 1987; Smith 2006; Campbell \& Gregor 2004; McCoy 2008, 702; Suoranta \& Ryynänen 2014).

Etnografinen tutkimustyö muodostui haastattelujen lisäksi toiminnan osallistuvasta havainnoinnista, keskusteluhetkistä osallistujien ja henkilökunnan kanssa sekä työtoiminnan arkeen osallistumisesta. Kuntouttavaan työtoimintaan osallistuvien haastatteluaineistosta $(\mathrm{N}=37)$ valikoitui tähän artikkeliin 11 haastattelua: kymmenen sanasta sanaan nauhoitettua ja litteroitua haastattelua ja yksi haastattelu, josta tehtiin haastattelutilanteessa kirjalliset muistiinpanot, jotka muunnettiin myöhemmin digitaaliseen tekstimuotoon. Aineiston valinnan perusteluna on ollut ensinnäkin se, että osallistuminen kuntouttavaan työtoimintaan on ollut selkeästi myönteinen käännekohta elämänkulun ja/tai elämänsisällön näkökulmasta. Myönteiset käännekohdat ihmisen elämänkulussa ovat elämäntapahtumia, joiden takia elämänkulun suunta muuttuu. Ne avaavat uusia mahdol- lisuuksia, tukevat elämänmuutosta ja saavat aikaan positiivisia kumulatiivisesti eteneviä ketjureaktioita (Oravala \& Rönkä 1999, 274-280). Toiseksi kaikille mukaan valikoituneille nykyinen kuntouttavan työtoiminnan jakso ei ole ensimmäinen.Tämä on siten heille uusi alku institutionaalisessa palvelujärjestelmässä syrjään jäämisen tai poiskäännyttämisen sijaan.

Tässä tutkimuksessa kuntouttavaan työtoimintaan osallistujat ovat iältään 27-56-vuotiaita. Heidän taustojaan yhdistää yksinasuminen. Heistä kaksi elää avoliitossa. Kolmella osallistujalla on joko ala- tai täysikäisiä lapsia. Ennen työtoimintaan tuloa enemmistö on ollut aikuissosiaalityön asiakkaana tai työttömänä. Moni on ollut elämänkulussaan hallinnon termein NEET-statuksella (Not in Employment, Education or Training) eli työn, koulutuksen ja harjoittelun ulkopuolella. Enemmistöllä koulutustaustana on peruskoulu. Osa on aloittanut erilaisia koulutuksia, jotka ovat keskeytyneet. Katkoksellinen työhistoria koostuu erilaisista siivousalan töistä, rakennustyömailla ja kuljetusalalla työskentelystä, kiinteistöhuollosta, varastotöistä sekä keittiö- ja ravintolaalan töistä.

Tutkimus perustuu sisällönanalyysille ja etnografiselle luennalle. Sisällönanalyysissä kenttäpäiväkirjaaineistoa käytettiin erityisesti kuntouttavan työtoiminnan sosiaalisten käytäntöjen ja työtoiminnan toimintamahdollisuuksien luokittelussa (Campbell \& Gregor 2004). Analysoinnin logiikka perustuu teoriasidonnaiseen, abduktiiviseen päättelyyn. Se on luonteeltaan vuorovaikutteinen prosessi, jossa päättely suuntaa yksityisestä 
yleiseen ja toisin päin. Oivallus analyysin teoreettisesta kehyksestä eli toimintamahdollisuuksien viitekehyksestä (Sen 2009) muotoutui etnografisen tutkimusprosessin aikana (Brewer 2000).

Analyysissä kiinnitettiin huomiota siihen, miten toimijuus suuntautuu kuntouttavassa työtoiminnassa. Aluksi alkuperäisestä tekstiaineistosta pelkistettiin sisällönanalyyttisesti ilmauksia, jotka ilmentävät toimintamahdollisuuksien kehyksen alaluokkia (Taulukko 1) ja niiden yhdistelmiä ensimmäiseen tutkimuskysymykseen vastaamiseksi. Luokittelun apuna oli ATLAS.ti-ohjelma. Aineiston analysointi jatkui etnografisella luennalla. Tutkimuslöydösten havainnollistamisessa hyödynnettiin narratiivisuutta (esim. Bruner 1987).

Analyysissä edettiin hermeneuttisesti haastateltavien kokemustiedosta ja havainnoista institutionalisiin suhteisiin, palaten jälleen syvempään analyysiin kokemustiedosta (Smith 1987; Smith 2006). Haastattelut olivat teemahaastattelun kaltaisia ja keskustelunomaisia kerronnallisia tiloja, joissa sekä haastateltava että tutkija saattoivat reagoida joustavasti puheeseen ja suunnata haastattelun kulkua. Osa haastatteluista toteutui hyvin etukäteen suunnitellusti, osa spontaanimmin työtoiminnan ja osallistujan tilanteen huomioiden. Haastattelut toteutuivat kuntouttavan työtoiminnan yksikön yhteydessä olevissa tiloissa. Tutkimus oli kuitenkin koko prosessin aikaista vuoropuhelua erilaisten toimijoiden kanssa. Analysointi perustui tehtyihin haastatteluihin ja kenttäpäiväkirja-aineistoon.
Hyvän tieteellisen käytännön mukaan tutkimusta ohjasivat osallistujien itsemääräämisoikeuden kunnioittaminen, tahdonvapaus, yksityisyyden ja tietosuojan säilyttäminen sekä haitan välttäminen (Hyvä tieteellinen käytäntö TENK; Kuula \& Tiitinen 2010; Brewer 2000, 90-95). Tutkimus käynnistyi yhteydenotoilla ja tutustumiskäynneillä kuntouttavan työtoiminnan yksiköihin, joissa tutkimuksen toteutuksesta keskusteltiin ensin vastuuhenkilöiden kanssa. Tutkimusta edelsi yksikkökohtaisten tutkimuslupien hakeminen ja niiden myöntäminen kolmessa eteläisen Suomen kaupungissa. Tämän jälkeen yksiköiden henkilökuntaa ja osallistujia informoitiin pääasiassa infokirjein. Kahdessa kolmesta yksiköstä toteutettiin ennen tutkimusta tiedotushetki, johon halukkaiden oli mahdollista osallistua. Tutkimukseen osallistujat, myös henkilökunta, antoivat kirjallisen suostumuksensa tutkimukselle. Osallistujille välittyi tieto osallistumisen vapaaehtoisuudesta ja mahdollisuudesta sen keskeyttämiseen missä vaiheessa tahansa ilman vaikutusta yksilön kohteluun tai palveluiden saantiin. Osallistujien kirjallisten tutkimuslupien lisäksi kaupungeilta saatiin yksikkökohtaiset tutkimusluvat. Tutkimusetiikka ja tietosuoja huomioiden emme käytä suoria tunnisteita osallistujista emmekä mainitse kaupunkeja tai työtoiminnan yksiköitä tutkimukseen osallistujien anonymiteetin varmistamiseksi. Tutkimuksen teon aikana saatua aineistoa on säilytetty hyvän tieteellisen käytännön mukaisesti. Tutkimusetiikka on kulkenut läpi koko etnografisen tutkimusprosessin perustuen tilanteiselle ja arkiselle etiikalle kohtaamisissa, haastattelutilanteissa ja keskusteluissa työtoiminnan yksiköissä. 
TOIMINTAMAHDOLlisuUdeT KUNTOUTTAVASSA TYÖTOIMINNASSA

Analyysin perusteella ja kansalaisoikeuksien näkökulmasta käsitämme työtoiminnan pitkään työttömänä olleiden suorittamana kansalaispalveluksena, jossa syntyi muodollinen, sopimuksellisuuteen ja määräaikaisuuteen perustuva jäsenyys yhteisössä. Voimauttava työtapa loi edellytyksiä voimavarojen ja toimintakykyisyyden vahvistumiselle ja voimavarojen käyttöönotolle. Yhteisökokoukset ja osallistujien vaikuttamismahdollisuudet sisältöihin olivat esimerkkejä siitä, miten deliberatiivista demokratiaa toteutettiin työtoiminnassa. Palvelua kehitettiin lisäksi asiakaskyselyillä. Työtoiminnan tilat olivat syrjinnästä vapaita ja monimuotoisia. Luontoretket, vierailut museoissa ja konserteissa sekä yhteiset juhlat vahvis-

Taulukko 2. Kooste työtoiminnasta toimintamahdollisuuksien näkökulmasta (mukaillen Cox ja Pawar 2013; den Braber 2013)

\begin{tabular}{|c|c|}
\hline Edellytykset & $\begin{array}{l}\text { Toimintamahdollisuuksien avaruus työtoiminnassa } \\
\text { ja sosiaaliset käytännöt }\end{array}$ \\
\hline $\begin{array}{l}\text { Poliittiset oikeudet } \\
\text { ja vapaudet }\end{array}$ & $\begin{array}{l}\text { Yhteisöllinen työote (kokemus kuulluksi tulemisesta, jaettu toimijuus) } \\
\text { Yksilön myönteinen tunnistaminen } \\
\text { Vapaus osallistua julkiseen ja kansalaisyhteiskunnan toimintaan: retket, } \\
\text { taidenäyttelyt, konsertit, vapaaliput tapahtumiin } \\
\text { Monikulttuurisuus ja syrjintäkielto }\end{array}$ \\
\hline $\begin{array}{l}\text { Materiaaliset } \\
\text { resurssit }\end{array}$ & $\begin{array}{l}\text { Työtoiminnassa jaettava ruoka-apu, aamiaiset, kierrätystavarat ja -vaatteet } \\
\text { Velkaneuvonta, ensiapukurssi, työturvallisuuskortti, vapaaliput tapahtumiin } \\
\text { Työtoiminnassa tehdyt oman työn päivän esineet } \\
\text { Työtoiminnan tilat, työvälineet ja laitteet }\end{array}$ \\
\hline $\begin{array}{l}\text { Sosiaaliset } \\
\text { mahdollisuudet }\end{array}$ & $\begin{array}{l}\text { Työtoiminnan mahdollistajat (vastuullinen johto ja työntekijät) } \\
\text { Kuntouttavan työtoiminnan intensiteetti ja riittävä kesto } \\
\text { Työ- ja toimintakykyisyyksien kasvu } \\
\text { Osaamisen vahvistuminen (opinnollistaminen) } \\
\text { Osallisuus ja syrjäytymisen ehkäisy } \\
\text { Myönteiset jatkumot ja siirtymät (ammatilliseen koulutukseen hakeutuminen) } \\
\text { Työtoiminnan ohjaus (vastuullinen ohjaus) } \\
\text { Omatyöntekijä } \\
\text { Opintoihin liittyvä ohjaus ja neuvonta (tutustumiskäynnit oppilaitoksiin, tuki } \\
\text { yhteishakuun) ja työtoiminnan opinnollistaminen } \\
\text { Terveystarkastukset, terveydentilan selvitys, mahdollisuus kuntoutusohjaukseen, } \\
\text { korvaushoito } \\
\text { Erilaiset työtoiminnan toiminnot: atk-kurssit, keskusteluryhmät, } \\
\text { päihteidenkäyttäjien vertaisryhmät, vertaisohjaus, liikunnalliset } \\
\text { harrastusmahdollisuudet (kuntosali, salibandy, kahvakuula, jumpat), teatteriryhmä, } \\
\text { ensiapukurssi, työturvallisuuskortti }\end{array}$ \\
\hline Avoimuus & $\begin{array}{l}\text { Osallisuuden kokemukset } \\
\text { Avoimuus organisaation toiminnassa ja taloudessa }\end{array}$ \\
\hline Perusturva & $\begin{array}{l}\text { Sosiaalivakuutuksen minimiturva (Kela) } \\
\text { Toimintaraha } \\
\text { Bussilippu/matkakorvaus } \\
\text { Sosiaaliturvajärjestelmä ja sen etuisuudet (toimeentulotuki) } \\
\text { Asumistuki vuokra-asuntoon }\end{array}$ \\
\hline
\end{tabular}


tivat täysivaltaista kansalaisuutta ainakin hetkellisesti. Kierrätettävien materiaalien käyttöä tunnuttiin arvostettavan.

Taulukossa 2 esitämme keskeiset tulokset kaikista viidestä toimintamahdollisuuksien ulottuvuudesta ja siitä, miten ne konkretisoituvat tutkimusaineistossa.

Aineiston perusteella päättelemme, että erityisesti pienituloisille tärkeitä toimintamahdollisuuksia olivat työtoiminnassa toimintaraha, ruoka-apu, yhteisruokailut, toimeentulotuesta maksetut bussi- ja junaliput, uimahalli- tai kuntosalikortit, tietokonekurssilla saatava euron tietokone ja ilmaiskontista saatavat vaatteet ja kirjat.

Sosiaalisia mahdollisuuksia avasivat mielekäs tekeminen ja uuden oppiminen, työtoiminnan opinnollistaminen, ammatilliseen koulutukseen haun suunnittelu sekä erilaiset kurssit kuten keskusteluryhmät ja päihteidenkäyttäjien vertaisryhmät. Sosiaaliset mahdollisuudet näkyvät siinä, että osallistujat asettivat tavoitteita toiminnalleen. Näköpiirissä oli myönteisiä tulevaisuushorisontteja, esimerkiksi tieto työtoiminnan jatkumisesta. ATK-taidot ja välineet edistivät osallistujien kykyä pärjätä digitalisoituvassa toimintaympäristössä. Työtoiminta itsessään saattoi lisätä kansalaistaitoja esimerkiksi silloin, kun siellä opastettiin vaalimaan käsityöläisperinteitä. Avoimuus viittasi niihin institutionaalisiin toimintatapoihin ja käytäntöihin, jotka edistävät osallisuutta, rakentavat sosiaalista pääomaa ja luottamussuhteita ihmisten kesken sekä ihmisten ja instituutioiden välille. Kokemus yhteenkuuluvuudesta lisäsi osallisuutta. Kuntouttavaan työtoimin- taan osallistuminen oli heille matalan kynnyksen palvelu ja toiminnan tila, joka kannatteli vaikeina hetkinä,ja jonne pääsi takaisin. Kokemus tasa-arvoisuudesta ja hyväksytyksi ja arvostetuksi tulemisesta koettiin tärkeänä. Osallistujien nimeämiä taloudellisen perusturvan lähteitä olivat työttömyyskorvaus, työtoimintaan osallistumisesta saatava matkakorvaus/toimintaraha, asumistuki sekä osan kohdalla toimeentulotuki. Kokonaisuudessaan työtoiminnan toimintamahdollisuuksien avaruus muodostuu siten monenlaisesta olemista, toimintaa ja päämäärien saavuttamista mahdollistavista asioista.

\section{ToimijuUden SUUnNAT}

Analyysin toisessa vaiheessa syvennyimme siihen, miten toimijuus suuntautuu kuntouttavassa työtoiminnassa, olipa sitten kyse omien voimavarojen kasvattamisesta, niiden käyttöönotosta ja kouluttautumisesta tai toimijuuden uudelleensuuntamisesta esimerkiksi pyrkimisestä avoimille työmarkkinoille. Kuntouttavan työtoiminnan hallinnon rationaliteetit ja käytännöt sisältävät sekä toimijuutta mahdollistavia että toimijuutta rajoittavia voimia (Smith 2005; 2006). Koska tutkimuksemme lähtökohtana oli kuntouttavaan työtoimintaan osallistuminen myönteisenä käänteenä elämässä, suuntautui toimijuus aineistossa $(\mathrm{N}=11)$ työtoiminnan jatkuvuuteen (5), työmarkkinoille (5) ja toimintamahdollisuuksiin työtoiminnan ulkopuolella (1). Työmarkkinoille suuntauduttiin kolmea reittiä: 1) ammatilliseen koulutukseen ja sitten töihin, 2) työkokeilun avulla töihin ja 3) suoraan työmarkkinoille. Havainnollistamme sitä, 
miten kuntouttava työtoiminta auttaa suuntaamaan toimijuutta Senin vapauksia kuvaavia skenaarioita soveltaen (Sen 2009, 229-230):

Positiivinen vapaus: vapaus olemiseen ja tekemiseen sekä arvostusten mukaisten tavoitteiden saavuttamiseen.

Negatiivinen / positiivinen vapaus: $\mathrm{Va}-$ pauden rajoittuminen olemisena ja tekemisenä, vapaus arvostusten mukaisten tavoitteiden saavuttamiseen.

Negatiivinen vapaus: Oleminen ja tekeminen sekä tavoitteiden saavuttaminen koetaan pakon sanelemaksi.

\section{Työtoiminta ponnahduslautana}

Skenaariossa A työtoiminta merkitsi mahdollisuutta kasvattaa voimavaroja ja opiskella uusia taitoja ohjauksen ja kokeilemisen avulla:

Täällä niitä voimavaroja pulpahtelee. Ei oo kotona kiva olla, ei hemmetti. Mä oon niin vähän aikaa vasta ollut. Vasta nyt alkaa tulla ajatuksia. Vuosi sitten ajattelin, että ei musta mitään tule. Oon vielä niin nuori. Tässä on yli kolmekymmentä vuotta työssäoloaikaa. Pakko tässä on alkaa jotain tekemään.

Osallistujat käyttivät arjen kekseliäisyyttä (Certeau 1984) suunnatessaan toimijuutta esimerkiksi maalaustekniikoiden kokeiluihin, työtilan hoitoon, työvälineistä huolehtimiseen ja ajankäytön suunnitteluun. Ilmaiseksi jaettavat kierrätysvaatteet, tavarat ja kirjat olivat mahdollisuus osallistuja kuluttajuuteen. Maksusitoumukset koulutuksiin kuten työturvallisuuskorttikoulutus ja kokeen läpäisy olivat pieniä etappeja, jotka avasivat puolestaan uusia toimintamahdollisuuksia. Skenaariossa A osal- listujan vapaus uusiin mahdollisuuksiin kasvoi, koska kuntouttavan työtoiminnan kautta hän löysi tien ammattioppilaitokseen ja koska toiminnan avulla hän oli alkanut vapautua elämää rajoittaneesta alemmuudesta.

Toimijuus voi alkaa suuntautua uudelleen, kun löytyy motivaatio - syy toimia toisin. Toimijuus suuntautuu uudelleen sellaisissa tapauksissa, kun ihminen motivoituu tavoittelemaan itselleen tärkeää asiaa, esimerkiksi hallitsemaan päihteiden käyttöään. Olennaista toimijuuden suuntautumisessa positiivisen vapauden kautta on se, että yksilö hallitsee tavoitteitaan ja valintojaan itse, vaikka hän haluaisikin niihin tuekseen muita ihmisiä, kuten omatyöntekijän.

\section{Työtoiminta jatkuvuutena}

Skenaario B kuvaa tilannetta, jossa työtoiminta rajaa vapautta olemiseen ja tekemiseen, mutta tekee kuitenkin mahdolliseksi arvostusten mukaisten tavoitteiden saavuttamiseen (Sen 2009). Tämä voi tarkoittaa esimerkiksi sitä, että kuntouttavan työtoiminnan velvoittavuutta pidetään ongelmallisena, mutta siitä huolimatta siihen halutaan osallistua joko siksi, että halutaan suuntautua työelämään tai siksi että elämään toivotaan mielekästä tekemistä ja yhteisöä.

Eräs kuntouttavaan työtoimintaan osallistuja sanotti työtoimintaa lintukodoksi ja pelastusrenkaaksi. Osallistuminen työtoimintaan oli hänen elämäntilanteessaan kannatteleva voima. Muita myönteisiä voimia olivat lapset ja lapsenlapset sekä mieluinen harrastus. Työhistoriaan kuului muun muassa siivousalalla työskentely. Vahingoittavasta 
parisuhteesta irrottautuminen oli helpottanut päihderiippuvuudesta kuntoutumista. Masennus ja itsetuhoisuus olivat varjostaneet arkea. Hän huolehtii läheistensä elämästä. Kuntouttavaa työtoiminta tarkoittikin omaa aikaa ja etäisyyttä muusta elämästä. Aiemmat saavutukset olivat voimavaroja, jotka auttoivat nykyhetkessä.

Mä nyt nautin tästä näistä päivistä ja näistä. En mä voi paljon eteenpäin suunnitella elämääni täs elämäntilantees kuitenkaan. En mä uskaltas vielä lähtee. Ei mun voimat.

Yhteiskunnan palvelujärjestelmän näkökulmasta kuntouttava työtoiminta oli hänen kohdallaan pelastava toimi (Eriarvoistumistyöryhmän loppuraportti 2018). Työtoiminta oli estänyt palvelujärjestelmässä väliinputoamista ja osoittanut, ettei työtoiminnan oven matalan kynnyksen ylittäminen ollut väärä teko (Määttä \& Keskitalo 2014).

Työtoiminta turvana tarkoitti tämän tutkimuksen aineiston valossa myös taloudellista turvaa. Siitä kertoi tutkimuksen aineistossa osallistuja, joka koki pärjäävänsä hyvin ilman työtoiminnan yhteisöä ja kuntoutumista. Toimintaraha ei ollut toimeentulemisen edellytys. Ammatillisen koulutuksen keskeytyminen, vuosia kestänyt päihderiippuvuus, avioero ja asunnottomuus olivat osa elämänhistoriaa. Nykyhetkessä eläminen loi hyvinvointia. Elämänlaatua ja positiivista vapautta toi puolestaan se, että saattoi toteuttaa työelämän ulkopuolella mieleisiä asioita ja tehdä esimerkiksi erilaisia hankintoja. Osallistuja haaveili matkasta ulkomaille tapaamaan ystäväänsä. Kolmen kuukauden jakso oli riittävä työtoimintaan sitoutumisen aikaväli.

Mä elän edelleenkin ihan päivän kerrallaan. Että mä en, mulla ei oo hirveesti mitään suunnitelmia. Tärkeintä on, että mä pysyn selvin päin, ni silloin mulla on kyl kaikki mahdollisuudet. Mut jos mä alan juomaan, ni mulla ei kyllä sit oo, sit tulee vaan takapakkia, eikä nää hommat edisty pätkääkään. Mulle on kyllä tos tarjottu duunia ja mulla selviä pätkiä aamulla ..., mutt ku mä en uskalla ottaa vastuuta silleen, että jos mä alan juomaan niin ei sitt ei viittii pettää toisten luottamusta.Täällä ei oo niin väliä vaikka mitä tapahtuis. Sitä ei nyt ota niin hirveen vakavasti.

Skenaariossa B vapautta rajoitetaan prosessin näkökulmasta. Toisaalta tämä skenaario sisältää positiivisen vapauden piirteitä siinä, että osallistujilla oli kokemuksia valitsemisen vapaudesta, esimerkiksi työtoiminnan luonteeseen ja sisältöön liittyen. Senin $(2009,225-$ 230) mukaan ihmisellä pitää olla mahdollisuus muuttaa mieltään. Keskeistä skenaarion B kannalta onkin, onko kuntouttavan työtoiminnan osallistujille annettu tilaisuutta muuttaa mieltään ja vaikuttaa asioiden tolaan. Jos sillä, miten lopputulokseen päädytään, ei ole merkitystä, voidaan vapaus katsoa positiiviseksi. Jos prosessilla puolestaan on merkitystä, vapaus on negatiivista. Vapaus ei ole kuitenkaan rajoittunut niin suuresti kuin skenaariossa C.Yksinkertaistaen voidaan väittää, että toisinaan voidaan päätyä tyydyttävään lopputulokseen hieman velvottavissa olosuhteissa. Silloin vapautta ei kuitenkaan saa rajoittaa lopputuloksen näkökulmasta. 


\section{Työtoiminta pakon sanelemana}

Skenaariossa C osallistuminen työtoimintaan on velvoittavaa. Pitkään työttömänä ollut voi kokea, että työttömyys on ainoa ongelma, mutta töitä ei löydy eikä kuntoutuksellisia tarpeita ole (Mäntyneva \& Hiilamo 2018). Työtä voi olla vaikea saada esimerkiksi matalan koulutuksen, iän, vieraskielisyyden, vamman tai yhteiskunnan asenteiden takia. Koska tämän artikkelin aineistoon valittiin vapaaehtoisesti kuntouttavaan työhön halunneita, skenaariota B ei voida havainnollistaa.

Yhteenvetona (kuvio 1) voidaan todeta, että toimijuus suuntautuu ensinnäkin työtoiminnassa jatkamiseen. Voimavarojen ja toimintakykyisyyksien vahvistaminen ja pienet elämänmuutokset ovat tällöin keskiössä. Yhden osallistujan osalta kuntouttavan työtoiminnan lyhytkestoisuus johti siirtymään toimintakykyä ylläpitävään työtoimintaan. Toisekseen toimijuus suuntautuu koulutukseen ja työelämään, johon yhteiskunta ohjaa osallistujia. Kun toimintaan osallistuminen on osallistujien omien tarpeiden ja arvostusten mukaista, se voidaan mieltää positiiviseksi vapaudeksi (Sen 2009). Työelämä toimijuuden suuntana edellyttää erilaisten kykyisyyksien, taitojen ja osaamisen kartuttamista. Toimijuuden suunta voi toki vaihtua joko äkillisesti tai jatkumonomaisesti liudentuen. Kolmantena toimijuuden suuntana on aktiivisuus työelämän ulkopuolella. Tällöin työtoiminnalla itsessään ei ole suurta merkitystä, mutta se mahdollistaa välillisesti päämäärien saavuttamisen esimerkiksi taloudellisen tuen ja yksinhuoltajan "työ- ja perhe-elämän" sovittamissa yhteen. Työtoiminta pakon sanelemana jäi käytetyn aineiston vuoksi tämän tutkimuksen ulkopuolelle.

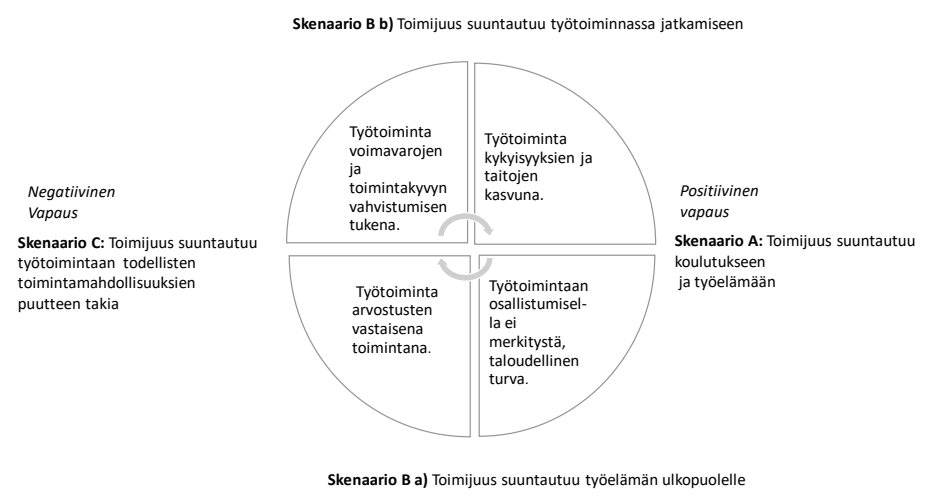

Kuvio 1. Toimintamahdollisuuksien avaruus ja toimijuuden suunnat 


\section{JOHTOPÄÄTÖKSET JA POHDINTA}

Kysyimme artikkelissa ensinnäkin sitä, millaisia toimintamahdollisuuksia kuntouttava työtoiminta tarjoaa. Keskeinen johtopäätöksemme on, että Coxin \& Pawarin (2013) viitekehyksessä kuntouttava työtoiminta muodostaa ideaalityyppisen mahdollisuuksien arkkitehtuurin, josta osallistuja voi valikoida makunsa mukaan toimintoja ja johon heitä varovaisesti rohkaistaan (Thaler \& Sustein 2009). Korjaavien toimien sijaan ennaltaehkäisevää toimintaa ovat inhimillinen päätöksenteko, mahdollisuuksien arkkitehtuuri, joka muuttaa ihmisten käyttäytymistä ennustettavalla tavalla sekä valintojen sensitiivisyys, mikä ei rajoita ihmisten vapautta (Koskiaho 2014, 14, 61-64

Päättelemme, että aineelliset toimintamahdollisuudet, joiden avulla ihmiset voivat saavuttaa uusia päämääriä, voivat olla muutakin kuin sosiaalivakuutus tai suora tulonsiirto toimeentulotukena. Esimerkiksi erilaisten maksusitoumusten käyttö (esim. ajokortti, kurssimaksut, vapaaliput tapahtumiin, tuetut lomat) nykyistä joustavammin voisi tukea sosiaalityön asiakkaiden selviytymistä omassa arjessaan ja toimintaympäristössään.

Tutkimme lisäksi sitä, miten toimijuus suuntautuu kuntouttavassa työtoiminnassa. Tutkimustuloksista voimme päätellä, että toimijuus suuntautuu 1) työtoiminnassa jatkamiseen, 2) koulutukseen ja työelämään ja 3) aktiiviseen elämään työelämän ulkopuolella. Ensimmäinen tarkoittaa sitä, että osallistuja saa turvattua elämän ja arjen jatkuvuuden. Tällöin on kyse voimavaraistavan toimintatavan ja toimintakykyisyyksien vahvistamisesta esimerkiksi sosiaalityön avulla.

Toinen suunnista noudattelee kuntouttavan työtoiminnan perinteistä ideaalia. Kuntouttava työtoiminta painottuu edelleen työhön: siinä jäljitellään palkkatyössä käyvän ihmisen arkielämää ja työssäkäyntiä rytmittämällä työtoimintaa tauoin, ryhmätoiminnoin ja retkin. Koulutukseen ja työelämään ohjautumisessa opinnollistamisen ja palveluohjauksen merkitys korostuu, ja näillä sisällöillä on vaikutusta yhteiskunnalliseen osallisuuteen.

Kolmannessa tilanteessa toimijuus suuntautuu kuntouttavan työtoiminnan ulkopuolelle. Kuntouttavaan työtoimintaan osallistuminen tuo taloudellista turvaa, joka auttaa saavuttamaan omien arvostusten mukaisia tavoitteita työelämän ulkopuolella. Työtoiminnalla prosessina ei tällöin ole erityistä merkitystä, eikä osallistumiseen sisälly työllistymis- ja kuntoutumistavoitteita.

Vaikka kuntouttava työtoiminta auttaa tutkimustulosten perusteella löytämään uusia toimijuuden koordinaatteja (Jyrkämä 2008), niin jaksot jäävät toimijuuden suuntautumisen näkökulmasta liian lyhytkestoiseksi. Yksilön negatiivinen vapaus ei ennätä voimavarojen, kykenevyyksien tai saavutusten näkökulmasta suuntautua uudelleen positiiviseksi vapaudeksi kuntouttavan työtoiminnan aikana (Sen 2009; Karjalainen \& Karjalainen 2010).

Työttömyys ei ole nyky-yhteiskunnan ainoa merkittävä riski. Ylisukupolvinen huono-osaisuus, syrjään jääminen, toisen asteen koulutuksen puuttuminen 25:n vuoden iässä, yksinhuoltajuus ja 
työn ja perhe-elämän yhdistäminen, työttömien toiminta- ja työkykyisyys ja addiktiot sekä velat ovat esimerkkejä elämäntilanteista, jotka kumuloituessaan rajaavat toimintamahdollisuuksia (Harkko 2018, Ruchstenstein ym. 2013). Ne vievät voimavaroja ja energiaa aiheuttaen kärsimystä ja kaventavat käytettävissä olevaa aikaa, mikä on tullut monissa tutkimuksissa esille (Frost \& Hoggett 2008; Mani ym. 2013). Silloin toimijuus suuntautuu selviytymiseen ja elämän jatkuvuuden ja toistettavuuden turvaamiseen. Palveluiden toteuttaminen siten, että ne tukevat selviytymistä ja luovat jatkumoja toimijuuden rajoitteita heikentäen luo todellisia toimintamahdollisuuksia työelämän suuntaan (esim. Saari ym. 2017).

Tämä tutkimus rajautui pienen empiirisen aineiston systemaattiseen analysointiin. Se tarjoaa siten enemmän teoreettisia ajatuksia kuin empiirisesti vahvaa näyttöä tai yleistettävyyttä. Skenaarioitten avulla olemme kuitenkin voineet havainnollistaa sitä, miten palveluiden luomat toimintamahdollisuudet avartavat tai supistavat ihmisten toimijuutta dynaamisena prosessina. Laajempi elämänkentän huomiointi ja aineisto olisi voinut monipuolistaa saatua tietoa. Etnografinen tutkimus tuotti pitkittäistä tietoa osallistujien näkökulmasta. Tutkimuksen muodostamat skenaariot perustuivat osin tulevaisuuden ennakoinnille tutkimukseen osallistujien tulevaisuushorisonttien perusteella. Olisikin tarpeen tutkia kuntouttavan työtoiminnan pidempiaikaisia seurauksia (Sen 2009).

Välttämätöntä on myös kysyä, miten sosiaaliturva, palvelut ja osallistaminen auttaa suuntamaan toimijuutta uudel- leen ja milloin velvoittavalla politiikalla ja toimenpiteillä on myönteisiä vaikutuksia (vrt. Wright 2012; Paz-Fuchs 2008, 21; Nussbaum 2011, 289-291; Kurki 2000; Peavy 1999; Pohjola 2017). Kuntouttavan työtoiminnan tarjontaan voisi lisätä poliittiseen toimijuuteen liittyviä sisältöjä ja vapaata sivistystyötä. Hallinnon- ja toimialojen yhteistoiminta muodostaisivat rakenteen, joka pitäisi pitkään työttömänä olleet yhteydessä erilaisiin yhteiskuntaryhmiin. Lainsäädännön, käytäntöjen ja toiminnan periaatteiden olisi tuettava ihmisten vuorovaikutusta paikallisyhteisöissä ja palveluissa sellaiseksi, että niistä viriää yksilöiden ja yhteisöjen näköpiiriin todellisia mahdollisuuksia ja toivon horisontteja.

\section{KiRJallisuUs}

Aho, Simo \& Tuomala, Juha \& Hämäläinen, Kari \& Mäkiaho, Ari (2018) Työvoimapalvelujen kohdistuminen ja niihin osallistuvien työllistyminen. Valtioneuvoston selvitys- ja tutkimustoiminnan julkaisusarja 19/2018. Helsinki: Valtioneuvoston kanslia.

Alkire, Sabina \& Deneulin, Séverine (2009) The Human Development and Capability Approach. Teoksessa Sabina Deneulin \& Lila Shanani (toim.) An Introduction to the Human Development and Capability Approach. London: Earthscan, 15-35. https://doi. org/10.4324/9781849770026

Archer, Margaret (1995) Realist social theory: The morphogenetic approach. Cambridge: Cambridge University Press. https://doi.org/10.1017/ CBO9780511557675

Björklund, Liisa \& Hallamaa, Jaana (2013) Miten kannustaa ihmisiä työmarkkinoille eettisesti ja kestävästi? Teoksessa Vappu Karjalainen \& Elsa Keskitalo (toim.) Kaikki työuralle! Työttömien aktiivipolitiikkaa Suomessa. Teema 18. Helsinki: 
Terveyden ja hyvinvoinnin laitos, 150172.

Bonvin, Jean-Michael (2008) Activation Policies, New Modes of Governance and the Issue of Responsibility. Social Policy \& Society 7 (3), 367-377. https://doi. org/10.1017/S1474746408004338

Bonoli, Giuliano (2010) The political economy of active labor-market policy. Politics \& Society 38 (4), 435-457. https:// doi.org/10.1177/0032329210381235

Breidahl, Karen \& Clement, Sanne (2010) Does active labour market policy have an impact on social marginalization? Social Policy \& Administration 44 (7), 845864. https://doi.org/10.1111/j.14679515.2010.00747.x

Brewer, John D. (2000) Ethnography. Understanding Social Research. Maidenhead, UK: Open University Press.

Bruner, Jerome (1987) Life as narrative. Social Research 54 (1), 11-32.

Campbell, Marie L. \& Gregor, Frances Mary (2004) Mapping Social Relations: A Primer in Doing Institutional Ethnography. Lanham (MD): AltaMira Press.

Card, David \& Kluve, Jochen \& Weber, Andrea (2010) Active labour market policy evaluations: A meta-analysis. The Economic Journal 120 (548), 452477. https://doi.org/10.1111/j.14680297.2010.02387.x

Carpenter, Mick \& Freda, Belinda \& Speeden, Stuart (2007) Beyond the workfare state. Labour Markets, Equalities and Human Rights. Chicago: University of Chicago Press. https://doi. org/10.2307/j.ctt9qgxtg

Certeau, Michel de (1984) The Practice of Everyday Life. Berkeley: University of California Press.

Cox, David \& Pawar, Manohar (2013) International Social Work: Issues, Strategies and Programs (2nd ed). London: Sage. https://doi. org /10.4135/9781544308685

Coffey, Amanda \& Atkinson, Paul (1996) Making sense of qualitative data: complementary research strategies. Thousand Oaks: Sage.

Den Braber, Collin (2013) The Introduction of the Capability Approach in Social Work Across a Neoliberal Europe. Journal of Social Intervention: Theory and Practice. 22 (4), 61-77. https://doi. org/10.18352/jsi.380

Elonen, Noora \& Niemelä, Jukka \& Saloniemi, Antti (2017) Aktivointi ja pitkäaikaistyöttömien monenlainen toimijuus. Janus 25 (4), 280-296.

Finch, Janet (1989) Family Obligations and Social Change. Cambridge: Polity Press.

Finch, Janet \& Mason, Jennifer (1993) Negotiating family obligations. The Sociological Review 38 (2), 219-246. https:// doi.org/10.1111/j.1467-954X.1990. tb00910.x

Freire, Paulo (1972) Pedagogy of Oppressed. 2nd ed. London: Penguin Books.

Frost, Liz \& Hoggett Paul (2008) Human Agency and Social Suffering. Critical Social Policy 28 (4), 238-460. https:// doi.org/10.2307/j.ctvdf065d.8

Giddens, Anthony (1984) The constitution of society. Outline of the theory of structuration. Cambridge: Polity.

Halvorsen, Knut (1998) Impact of Reemployment on Psychological Distress among Long-term Unemployed. Acta Sociologica 41 (2-3), 227-242. https:// doi.org/10.1177/000169939804100213

Hammersley, Martyn \& Atkinson, Paul (2007) Ethnography. Principles in practice. Third Edition. London, New York: Routledge.

Hannula, Aino (2000) Tiedostaminen ja muutos Paulo Freiren ajattelussa: systemaattinen analyysi Sorrettujen pedagogiikasta. Helsingin yliopiston kasvatustieteen laitoksen tutkimuksia 167. Helsinki: Helsingin yliopisto.

Harkko, Jaakko (2018) Transitions to adulthood among Finnish young people: a mixed-methods study based on longitudinal register data and interviews with street-level professionals.Väitöskirja. Valtiotieteellisen tiedekunnan julkaisuja 102. Helsinki: Helsingin yliopisto.

Hiilamo, Heikki \& Saari, Juho (2010) Hyvinvoinnin uusi politiikka - johdatus sosiaalisiin mahdollisuuksiin. 107-134. Diakonia-ammattikorkeakoulun julkaisuja A Tutkimuksia 27, 2010. Helsinki: Diakonia-ammattikorkeakoulu.

Hiilamo, Heikki (2014) Voisiko osallistava sosiaaliturva lisätä osallisuutta? Yhteiskuntapolitiikka 79 (1), 82-86.

Hiilamo, Heikki \& Komp, Kathrin \& 
Moisio, Pasi, Babila, Sama \& Thomas \& Lauronen, Juha-Pekka \& Karimo, Aasa \& Mäntyneva, Päivi \& Parpo, Antti \& Aaltonen, Henri (2017) Neljä osallistavan sosiaaliturvan mallia. Valtioneuvoston selvitys- ja tutkimustoiminnan julkaisusarja: 18/2017. http://urn.fi/ URN:ISBN:978-952-287-351-4 Luettu 8.2.2017.

Hoggett, Paul (2000) Emotional life and the politics of welfare. London: Palgrave Macmillan. https://doi. org/10.1057/9780230597815

Hoggett, Paul (2001) Agency, Rationality and Social Policy. Journal of Social Policy 30, 1. Cambridge University Press, 3756.

Honneth, Axel (2012) The I in We: studies in the theory of recognition. Cambridge (MA): Polity Press.

Hämäläinen, Juha (2008) Nuorten osallisuus. Sosiaalipedagoginen aikakauskirja, vuosikirja 2008, 9. vuosikerta. Kuopio: Suomen Sosiaalipedagoginen seura ry, 13-34.

Hyvä tieteellinen käytäntö TENK. https:// www.tenk.fi/fi/tenkin-ohjeistot Luettu 15.8.2014

Jyrkämä, Jyrki (2008) Toimijuus, ikääntyminen ja arkielämä - hahmottelua teoreettis- metodologiseksi viitekehykseksi. Gerontologia 22 (4), 190-203.

Karjalainen, Vappu (2013) Työttömän palvelujärjestelmän aktivoituminen. Teoksessa Vappu Karjalainen \& Elsa Keskitalo (toim.) Kaikki työuralle! Työttömien aktiivipolitiikkaa Suomessa. Teema 18. Helsinki: Terveyden ja hyvinvoinnin laitos, 99-119.

Karjalainen, Jarno \& Karjalainen, Vappu (2010) Aktiivista sosiaalipolitiikkaa vai työllisyyspolitiikkaa? Empiirinen tutkimus pääkaupunkiseudulla. Raportti 38/2010. Helsinki: Terveyden- ja hyvinvoinnin laitos.

Kivipelto, Minna \& Saikkonen, Paula (2017) Sosiaalityö ekologisiin rajoihin mahtuvassa hyvinvointivaltiossa? Teoksessa Sakari Hänninen \& Paula Saikkonen (toim.) Hyvinvointi ylittää jälkensä. Helsinki: Terveyden ja hyvinvoinnin laitos, 25-39.

Koskiaho, Briitta (2014) Kumppanuuden sosiaalipolitiikkaa etsimässä. Helsinki:
Suomen Setlementtiliitto ry.

Kurki, Leena (2000) Sosiokulttuurinen innostaminen. Muutoksen pedagogiikka. Tampere:Vastapaino.

Kuula, Arja \& Tiitinen, Sanni (2010) Eettiset kysymykset ja haastattelujen jatkokäyttö. Teoksessa Johanna Ruusuvuori, Pirjo Nikander \& Matti Hyvärinen (toim.) Haastattelun analyysi. Tampere: Vastapaino.

Kuusela, Pekka (2011) Sosiaalitieteet, sosiaalisuus ja sosiaalisen toiminnan teoria. Teoksessa Tuija Kotiranta, Petteri Niemi \& Raili Haaki (toim.) Helsinki: Gaudeamus, 51-71.

Laitinen, Merja \& Niskala, Asta (toim.) (2013) Asiakkaat toimijoina sosiaalityössä. Tampere:Vastapaino.

Leemann, Lars \& Nørup, Iben \& Clayton, Stephen (2016) The health impacts of active labour market policies. Data brief 28. Helsinki: Terveyden ja hyvinvoinnin laitos. http://www.julkari. fi/bitstream/handle/10024/131620/ URN_ISBN_978-952-302-794-7. pdf? sequence $=1$ \&isAllowed $=\mathrm{y}$

Lister, Ruth (2004) Poverty. Cambridge: Polity.

Lødemed, Ivar \& Trickey, Heather (2001) An Offer You Can't Refuse. Workfare in international perspective. Bristol, UK: The Policy Press. https://doi.org/10.1332/ policypress/9781861341952.001.0001

McCoy, Liza (2008) Institutional Ethnography and Constructionism. Teoksessa James A. Holstein \& Jaber F. Gubrium (toim.) Handbook of Constructionist Research. The Guildford Press, London and New York, 701-714.

Mani, Anandi \& Mullainathan, Sendhil \& Shafir, Eldar \& Zhao, Jiyaying (2013) Poverty Impedes Cognitive Function. Science 341 (6149), 976-980. https:// doi.org/10.1126/science.1238041

Määttä, Anne \& Keskitalo, Elsa (2014). Ulkoringiltä sisärinkiin. Kumuloituneista ongelmista kärsivät nuoret aikuiset pirstaleisessa palvelujärjestelmässä. Yhteiskuntapolitiikka 79 (2), 197-207.

Mäntyneva, Päivi \& Hiilamo, Heikki (2018) Osallisuuden ja osattomuuden dynamiikka. Etnografinen tutkimus kolmella kuntouttavan työtoiminnan kentällä.Yhteiskuntapolitiikka 2018 (1), 18-28. 
Mäntyneva, Päivi (2019) Toimijuuden vahvistumisen edellytykset kuntouttavassa työtoiminnassa. Hyväksytty käsikirjoitus (15.3.) Sosiaalipedagogiseen aikakauskirjaan 2019.

Nivala, Elina (2008) Kansalaiskasvatus globaalin ajan hyvinvointiyhteiskunnassa. Kansalaiskasvatuksen sosiaalipedagoginen teoriakehitys. Väitöskirja, Kuopio: Kuopion yliopisto.

Nivala, Elina \& Ryynänen, Sanna (2013) Kohti sosiaalipedagogista osallisuuden ideaalia. Sosiaalipedagoginen aikakauskirja. Vuosikirja 2013. 14. vuosikerta. Kuopio: Suomen sosiaalipedagoginen seura ry, 9-42.

Nussbaum, Martha (2011) Creating capabilities: the human development approach. Cambridge Mass.: The Belknap Press of Harvard University Press.

Oivo, Tuija \& Kerätär,Tuija (2018) Osatyökykyisten reitit työllisyyteen - etuudet, palvelut, tukitoimet. Selvityshenkilöiden raportti. Sosiaali- ja terveysministeriön raportteja ja muistioita 43/2018. Helsinki: Sosiaali- ja terveysministeriö.

Oravala, Sanna \& Rönkä, Anna (1999) Käännekohdat elämänkulussa. Psykologia 34 (4), 274-280.

Paz-Fuchs, Amir (2008) Welfare to Work: Myth and Fact, Social Inclusion and Labour Exclusion. Oxford Journal of Legal Studies 28 (4), 797-811. https://doi. org/10.1093/ojls/gqn018

Peavy, R. Vance (1999) Sosiodynaaminen ohjaus. Suom. Petri Auvinen. Helsinki: Psykologien Kustannus Oy.

Pohjola, Anneli (2017) Asiakkaan pitkä tie palveluihin vaikuttajaksi. Teoksessa Anneli Pohjola, Maarit Kairala, Hannu Lyly \& Asta Niskala (toim.) Asiakkaasta kehittäjäksi ja vaikuttajaksi - Asiakkaiden osallisuuden muutos sosiaali- ja terveyspalveluissa. Tampere:Vastapaino, 308-325.

Robeyns, Ingrid (2005) The Capability Approach:a theoretical survey.Journal of Human Development 6 (1), 93-117.https:// doi.org/10.1080/146498805200034266

Ruchstenstein, Minna (2013) Raha ja addiktiot ajan syklisessä taloudessa. Teoksessa Tuukka Tammi \& Pauliina Raento (toim.) Addiktioyhteiskunta. Riippuvuus aikamme ilmiönä. Gaudeamus, 165-180.
Roivainen, Irene \& Heinonen, Jari \& Ylinen, Satu (2011) Köyhä byrokratian rattaissa. Helsinki: Kunnallisalan kehittämissäätiö.

Saari, Juho \& Merikoski, Laura \& Behm, Miia (2017) Teoksessa Juho Saari (toim.) Oman elämänsä asiantuntijat - Selviytyminen viimesijaisella turvalla. Sosiaaliturvariippuvuus. Sosiaalipummit oleskeluyhteiskunnassa?, 287-318.

Saikkonen, Paula \& Blomgren, Sanna \& Karjalainen, Pekka \& Kivipelto, Minna (2015) Poistaako sosiaalityö huonoosaisuutta? KAKS - Kunnallisalan kehittämissäätiö. Tutkimusjulkaisu-sarjan julkaisu nro 89. Helsinki: Kunnallisalan kehittämissäätiö.

Saikku, Peppi (2018) Hallinnan rajoilla. Monialainen koordinaatio vaikeasti työllistyvien työllistämisen edistämisessä. Helsingin yliopisto: Valtiotieteellisen tiedekunnan julkaisuja $74 / 2018$. Helsinki: Helsinki UniPress.

Sen, Amartya \& Nussbaum, Martha (1993) The Quality of Life. Oxford: Oxford University Press. https://doi. org/10.1093/0198287976.001.0001

Sen, Amartya (1999) Freedom as development. Oxford: Oxford University Press.

Sen, Amartya (2009) The idea of justice. Cambridge Mass.: Belknap Press of Harvard University Press.

Siisiäinen, Martti (2010) Osallistumisen ongelma. Kansalaisyhteiskunta 1 (1), 4-40.

Smith, Dorothy (1987) The everyday world as problematic: A feminist sociology. Toronto: University of Toronto Press.

Smith, Dorothy (2005) Institutional Ethnography: Sociology for People. Oxford: AltaMira Press.

Smith Dorothy (2006) Institutional Ethnography as Practice. Oxford: Rowman \& Littlefield.

Suoranta, Juha \& Ryynänen, Sanna (2014) Taisteleva tutkimus. Helsinki: Into.

Thaler, Richard H. \& Sustein Cass R. (2009) Nudge. Improving Decisions About Health, Wealth, and Happiness. London: Penguin Books.

Terävä, Eeva,Virtanen, Petri, Uusikylä, Petri \& Köppä, Lassi (2011) Vaikeasti työllistyvien tilannetta ja palveluita selvittävä tutkimus. Työ- ja elinkeinoministeriön 
julkaisuja.Työ ja yrittäjyys. 23/2011. Helsinki:Työ- ja elinkeinoministeriö.

Therborn, Göran (2014) Eriarvoisuus tappaa. Suom. Tatu Henttonen. Tampere: Vastapaino.

Vaarama, Marja (2011) Sosiaalipolitiikan nykytila. Teoksessa Elina Palola \& Vappu Karjalainen (toim.) Sosiaalipolitiikka hukassa vai uuden jäljillä? Helsinki: Terveyden ja hyvinvoinnin laitos, 15-29.

Walters, William (2000) Unemployment and Government: Genealogies of Social. Cambridge: Cambridge University Press. https://doi.org/10.1017/ CBO9780511557798
Wright, Sharon (2012) Welfare-towork, Agency and Personal Responsibility. Journal of Social Policy 41 (2), 309-328. https://doi.org/10.1017/ S0047279411001000

Ylikännö, Minna (2017) Työttömät palvelujärjestelmän heittopusseina. Teoksessa Annamari Tuulio-Henriksson, Laura Kalliomaa-Puha, Pirkko-Liisa Rauhala \& Marketta Rajavaara (toim.) Harkittu, tutkittu, avoin. Marketta Rajavaaran juhlakirja. Kelan tutkimusjulkaisuja. Helsinki: Kela, 111-130. 